\section{Mama Said There'd Be Days Like This - My Life in the Jazz World}

\section{Val Wilmer}

The Women's Press: London 1989

ISBN $0704350408 \mathrm{Hdbk} £ 16.95$

At the outset of her book, music journalist and photographer Val Wilmer states the terms on which she offers us the story of her life in jazz: 'People often write autobiographies as if they had no mother, no children, as if sexual love had passed them by. This is not one of those.'The book then proceeds in an unashamedly anecdotal way; it would be perverse to read it in hope of theory, and worse to judge it thereby.

The refreshingly unembellished detail of South London in the fifties provides us with an idea of the physical, social and musical environment of her growth. The unfolding of this life is simple, but what unfolds is remarkable. Only occasionally recalling a moment when her young enterprise gave her cause for wonder, she recounts, for the most part, a series of encounters that would have been unimaginable for most of us at that age. The Streatham tomboy with a compatible little brother and a hard-working mother who let rooms in their house, became an adolescent girl whose energy and activity was exceptional, but recognizable. When Valerie's passion for recorded music and a growing specialization in jazz drove her to the roots of that music and its creators, those younger energies and abilities were rapidly converted to something rarer. Writing letters out of the blue to the Jazz Greats, who almost invariably responded with a generosity not often associated with stardom, scraping together the cash for concerts, endlessly hanging around backstage - these were the messy beginnings of an ultimately welldefined opus.

Because Val doesn't fall into the trap of autobiographic anachronism, the reader has a satisfying sense of growing up alongside the protagonist; the simplicity of events and lack of interpretation early on, give way to a more philosophical and analytical view later in the book, when such processes are more accurate representations of what age and experience has furnished.

There's also that nice sense of the hobby and the profession being unrelated at the start - that the vision of her ambition was of fag in mouth 'bashing out the news' in Fleet Street, that she took a course in photography with little enthusiasm, and that jazz was still, at that stage, a passionate pastime. The result is an enjoyable frisson between these disparate elements, and our knowledge of what their combination eventually produced.

It is left to us to speculate what it is that moves some women to make the leap. In this instance Valerie Wilmer, an English lower-middleclass, young, white woman, began hacking out a path from a jungle of prejudice and ignorance about the realities of Black music. This music was rapidly usurped from the originators by modern market-makers, and most of us were content to consume the product and take little or no notice of the means of production or the origin and kind of raw materials used. It's obvious from the very beginning of this impressive saga, set in London, New York, the deep South, and Africa, that young Valerie would never be content to separate the music from the people who played it.

And working from the heart clearly drew flack: from the jazz scene in general which regarded all young unattached women hangersabout as star-fucking hopefuls, from white peers of both sexes who were suspicious about anyone who stayed so close to Black players and their community, and later, when feminism fell short of encompassing her early behaviour. Because Val is so disarmingly honest about the facts, and in the telling of her story, it's 
easier to see now that the problems lay in the inflexibility of all those armchair observers and their difficulties with someone who refused to hide behind manufactured objectivism or the inconsistencies of theory.

She was right to be unapologetic about her style. Her legacy is not only the deeply and painstakingly secured documentation of the core of contemporary popular music, but also, with this book, the inside story of how a young woman can persist in following her passion on her terms against some very subtle and not so subtle odds. What a loss it would have been had Val succumbed at any stage to the pressures of decorum, theory or peer pressure and given up or denied any of the apparently contrary elements of the way she has managed to conduct her work and life. There's a feeling that for many years Val has had to soft-pedal her early years, to abandon the complex truths about all that caring love of the music and people of the vast African diaspora to a slightly dismissive ferment of rumour and misunderstanding: and that similarly she has had to be a little less open than she would like to have been (and even then, never covert) about the nature of her sexuality, as complex as it is with all of us, in those music and journalistic circles which might have closed its doors to her had she done so. With this book Val has made the courageous decision to tell it like it was. The result is a social history of music like no other, and a no-nonsense account of the development from birth to maturity of a dynamic woman whose documentary arts deserve to be reappraised as a whole in the light of this book.

She is not afraid to judge some of her steps as mistakes, nor reconstruct the myriad battle-fronts she encountered in her attempt to step outside the accepted confines her society and professions demanded. In resurrecting the countless, clearly painful times her right as a White Woman to enter into and comment on a Black world was challenged, Val admirably resists political defence, and steadfastly sticks to telling that wonderfully rich, at times much to be envied, story. We are privileged, as comfortable readers, conveniently protected from the dangers of the front line which she continued to brave, to meet the real characters, their friends and families, and uncelebrated members of the society from which the music sprang. We learn at close hand what the woman was doing with her time all those years. To all outward appearances unstructured, shambling, utterly non-academic, the apprenticeship Val Wilmer chose for herself and then invented as she went along, saw her pursuing 'the knowledge' in a thorough, impassioned, self-motivated and exuberant way which is unique to the true scholar of any age.

There are quibbles, but these have more to do with production than content. The absence of a firmer editorial hand leaves us with perhaps too many of the very small and ultimately intrusive 'mentions' which seem only to have survived because of the author's desire to leave no one out. While the sentiment and show of respect is admirable, it does make for a jerky read up front. Less pardonable is the sloppy proofing, and the strange irony that has this particular artist, smiling and in her element, relegated to the back (cover) of the book, like so many of the fellow artists whose work she has spent her life documenting.

\section{Robyn Archer}

